\title{
Pigmented naevi and sun protection behaviour among primary and secondary school students in an Eastern Hungarian city
}

\author{
Emese Gellén ${ }^{1}$, Eszter Janka ${ }^{1, *}$, Ildikó Tamás ${ }^{1}$, Ádám Balázs ${ }^{2,3}$, Irene Horkay ${ }^{1}$, Gabriella Emri ${ }^{1}$ \& \\ 2 Éva Remenyik ${ }^{1}$
}

\begin{abstract}
${ }^{1}$ Department of Dermatology, Faculty of Medicine, University of Debrecen, Debrecen, Hungary.

${ }^{2}$ Department of Preventive Medicine, Faculty of Public Health, University of Debrecen, Debrecen, Hungary.

${ }^{3}$ Institute of Public Health, College of Medicine and Health Sciences, United Arab Emirates University, Al Ain, United Arab Emirates.
\end{abstract}

\section{Key words:}

indoor tanning; melanocytic naevi; school children; sun protection; sun-safe behaviour

\section{Correspondence:}

Éva Remenyik, Nagyerdei krt. 98., Debrecen 4032, Hungary.

Tel: +36 52/255 204

Fax: $+3652 / 255736$

e-mail: remenyik@med.unideb.hu

\section{Accepted for publication: 12 October 2015}

\section{Conflict of interest:}

The authors have no conflict of interest.

*Co-first author: This author contributed equally to this work.

\section{SUMMARY}

\section{Background}

The most important risk factors for malignant melanoma are skin type I or II, large number of atypical naevi and a history of sunburn in childhood and adolescence.

\section{Methods}

A cross-sectional study was performed to assess skin type, number of pigmented lesions and sun protection behaviour in 1157 12- to 19-year-old Hungarian students at 20 primary and secondary schools in Debrecen, Hungary. After receiving dermatological training, 18 school doctors examined the students' skin. A questionnaire was completed by the students with the assistance of their parents about sun protection, sunburns and the use of sunbed. Data from 612 questionnaires were evaluated.

\section{Results}

Based on the doctors' evaluation, most of the pupils were classified as having skin type II and majority of them had 5-20 naevi, particularly on the trunk. Based on the student's response, 5.2\% purposely sunbathed daily, $10.1 \%$ did not use any form of sun protection, $32.2 \%$ wore sun-protective clothing and $65.7 \%$ applied sunscreen generally. $6.9 \%$ used sunbed, and $74.0 \%$ previously experienced serious sunburn at least once. Indoor tanning statistically correlated with the number of melanocytic naevi.

\section{Conclusion}

A high prevalence of sunburn was reported by the students and some of them did not apply any sun protection methods but used sunbed at a critical age for developing melanoma at a later time. These data highlight the importance of educating children and parents about appropriate sun protection.

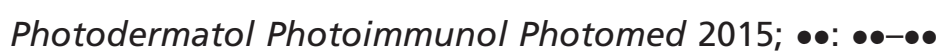


The incidence of malignant melanoma (MM) and non-melanoma skin cancers (NMSC) is increasing worldwide (1-3). The incidence of $\mathrm{MM}$ is 4-19 per 100000 individuals in Europe (4), and the incidence of NMSC is approximately 100 per 100000 individuals (5). The UV index in Hungary can reach $8-10$ in summer. The incidence of skin cancer was 140 per 100000 individuals in Hungary in 2008 (14 026 new cases). The raw incidence rates of $\mathrm{MM}$ in the same year were 20.4 per 100000 male inhabitants and 21.6 per 100000 female inhabitants, according to the National Registry (6).

Fair skin, a large number of naevi and freckles (especially on the shoulders), the presence of atypical naevi, a family history of MM, a history of more than three severe sunburns before 20 years of age, male gender and chronic UV exposure are all risk factors for the development of MM (7-11). The presence of one or two criteria from the above risk factors increases the risk by 2 - to 4 fold, and the presence of more than three risk factors results in a 20 -fold increased risk for the development of melanoma in the future compared with the general population (12-14).

The number and severity of a person's sunburns are the most important risk factors. The risk of melanoma doubles in people who have experienced at least one sunburn (15). An increasing number of new naevi is more likely to be associated with intermittent intensive (midday hours) UV exposure $(16,17)$. One metaanalysis suggested that not only sunlight but also the use of sunbed can increase the risk of melanoma, and this risk is more prominently associated with the long-term use of sunbeds at young ages (18).

The treatment of MM in its late stages is usually unsuccessful. These lesions do not respond appropriately to conventional anticancer therapies. Although promising immunological and targeted treatment modalities are available, early in toto excision of the lesions remains the most important factor for overall survival. Therefore, early recognition and primary prevention are essential.

No data were available regarding Hungarian students' sun protection behaviours and sunbathing habits when the study was designed. Therefore, our primary aim was to assess sun behaviour and protection habits of urban 12- to 19-year-old Hungarian students and compare these data with international data. Our secondary aim was to train school doctors regarding how to evaluate naevi and recognise atypical naevi through physical examinations. Thus, we also intended to assess how these doctors can be involved in the primary prevention of MM.

\section{METHODS}

\section{Site of the study}

The study was conducted in Debrecen, which is the second largest city in Hungary with 220000 residents, and it is located in the sunny Great Plain of the Carpathian Basin in Central Europe, which has approximately 2000 sunny hours per year.

\section{Study design and sample}

After receiving dermatological training (which included Fitzpatrick skin phenotype classifications, the evaluation of naevi, recognition of atypical naevi, types and risk factors of MM based on several characteristic clinical pictures, and sun protection methods) by dermatologists working at the Department of Dermatology University of Debrecen Medical Centre, 18 school doctors evaluated the students' skin status, including skin type and number of naevi. These assessments were conducted in 20 public schools in Debrecen (12 elementary and eight secondary schools) during annual health evaluations, when every child in a certain age/school grade must be examined. Before the study was designed, the principals of the schools were informed personally, and they all agreed to participate in the study. The primary school students were $12-$ to $15-$, and the secondary school students were 15- to 19-year-old.

Through physical examinations of the students, the school doctors assessed the number and locations of melanocytic naevi ('Well-circumscribed, round to ovoid lesions, generally measuring from 2 to $6 \mathrm{~mm}$ in diameter. They appear orderly and symmetric overall. Although many naevi display slight asymmetry, the borders are usually regular and well defined.') (19) and determined the number of atypical naevi (i.e. naevi with asymmetry, irregular border, more than one colour and larger than $6 \mathrm{~mm}$ or naevi different from other naevi of the same individual). The doctors also determined the skin phototype with the pursuance of Fitzpatrick classification, which is the most common method for assessing sunburn risk, for each student according to the colour of their hair, eyes, and skin and reactions to sunlight, ranging from skin type $\mathrm{I}$, who never tan and always burn, to skin type VI, who deeply pigmented and never burn. All of the students were categorised into four skin type groups (I-IV), most of them categorised as type II. Before the physical examination, the students completed a questionnaire about their sun protection habits with the assistance of their parents. 
Appropriate sun protection consisted of the application of sunscreen, the wear of sun-protective clothing (long-sleeved clothing), staying in the shade, and the use of a hat. Inappropriate sun protection referred to the lack of the above mentioned factors.

\section{Questionnaire}

This questionnaire was created by dermatologists from the Department of Dermatology and included 44 questions, of which 29 were related to Fitzpatrick skin phototypes, sunbathing, sun protection habits (application of sunscreen, wear of sun-protective clothing, staying in the shade, use of a hat) and sunbed use. Family histories of skin cancer, neonatal blue-light therapy, previous phototherapy and any skin disease were also asked, although these data were not used in the study.

Three ranges were defined for the numbers of naevi based on the literature and our professional experience, namely $<5,5-20$, and more than 20 as multiple naevi $(20,21)$.

\section{Ethics and approval}

The questionnaire received ethical approval from the Regional Ethical Committee (certificate number: 2592/ 2007). The parents were aware of the content of the questionnaire and in addition with their children provided their consent.

\section{Statistical analyses}

Data of percentages and mean \pm standard deviation were analysed by descriptive statistics. The significance of differences in the number of sunburns among primary and secondary school student was determined by two-sample $t$-test. Sun protection methods and sunbathing habits among primary and secondary school students were demonstrated by Fisher's exact test and chi-squared test. The influencing factors of sunburn were analysed according to the skin type, age (primary school students: $12-15$ years, secondary school students: 15-19 years), gender, hair-, eye colour, sunbathing, application of sunscreens and sun protective clothing by binomial logistic regression. Furthermore, for the investigation of factors influencing the number of naevi, multinomial logistic regression was applied. SPSS (version 19.0; SPSS Inc., Chicago, IL, USA) software was used for statistical analyses. Data were graphically represented using Excel 2010 (11.5612.5606). Statistical significance was established at the $5.0 \%$ significance level.

\section{RESULTS}

\section{Sample description}

The sample size consisted of 1157 students. All of the students completed the questionnaire, but only 612 returned questionnaires were eligible for analysis (all of the questions were answered and the questionnaire was filled out properly). The mean age of the surveyed primary school students (393 students) was $13.16 \pm$ 0.55 years, while the mean age of the secondary school students (219 students) was $17.09 \pm 0.56$ years. The gender ratio of boys to girls was $1: 1.25$.

School doctors assessed the skin types and numbers of naevi of the 1157 students. In this cohort, the mean age of the primary school students (704 persons) was $13.11 \pm 0.50$ years, whereas the mean age of the secondary school students (453 persons) was $17.06 \pm$ 0.55 years. The male-to- female ratio in the study population was $1-1.06$.

\section{SELF-REPORT QUESTIONNAIRE SURVEY}

\section{Sunbathing habits according to the age group and gender}

Sunbathing during holidays was reported by $39.2 \%$ of primary and $23.3 \%$ of secondary school students, and daily or weekly sunbathing was reported by $15.0 \%$ of primary and $23.7 \%$ of secondary school students. Sunbathing was more popular among girls than boys in both age groups (primary school girls: $75.0 \%$, secondary school girls: $75.0 \%$, primary school boys: $44.0 \%$, secondary school boys: $48.0 \%)$.

\section{Time of sun exposure during holidays}

Both primary and secondary school students reported spending approximately $6 \mathrm{~h} /$ day outdoors during holidays (5.82 \pm 2.84 and $6.16 \pm 3.02 \mathrm{~h} /$ day, respectively) (Fig. 1a). In total, $63.6 \%$ of the students (389 persons) reported spending more than $4 \mathrm{~h}$ outside (primary school: $60.6 \%, 238$ students; secondary school: $69.0 \%, 151$ students), and $30.3 \%$ of the younger and $33.3 \%$ of the older students reported spending more than $6 \mathrm{~h} /$ day outside during holidays (Fig. 1a). Most of the students avoided sunbathing at midday (Fig. 1b) 
Gellén et al.
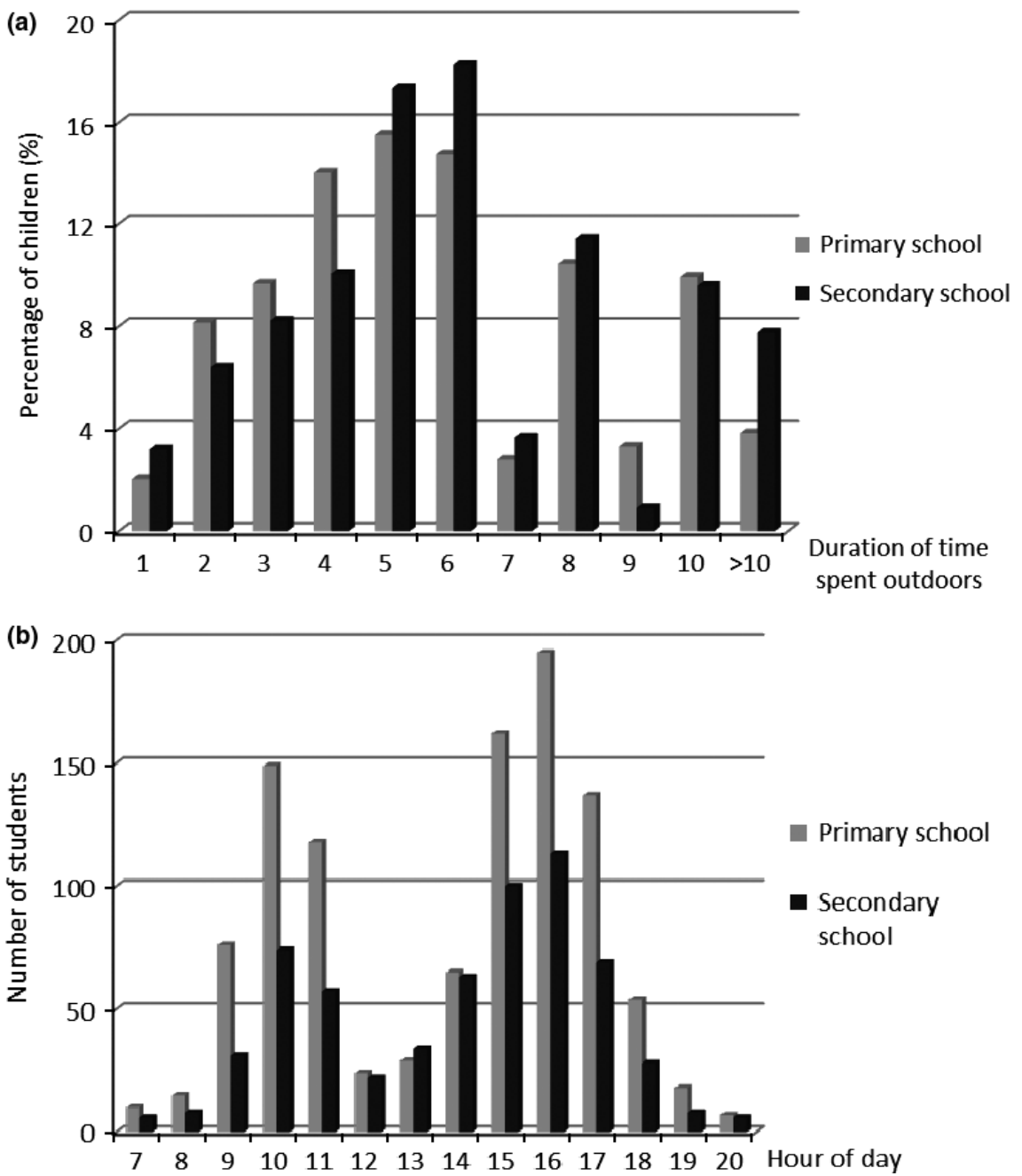

Fig. 1. (a) The percentage of children spending set periods of time outdoors during summer holidays comparing primary (age 12 - $\mathbf{Z}$ 15 years) and secondary (age 15-19 years) school children as measured using self-reported data. (b) Time of day when primary and secondary school students were sunbathing during average summer days.

\section{Number of sunburns according to the age group and gender}

The survey showed that $10.1 \%$ of the students did not use any sun protection methods and 5.2\% of the students purposely sunbathed (Table 1 ). Particularly noteworthy was the finding that $23.0 \%$ and $21.0 \%$ of secondary school boys and girls, respectively, with skin type I did not apply any sun protection methods. Seventy-four percentage of students (451 students) reported experiencing severe sunburn in their lifetime, and $43.3 \%$ of primary school students (170 persons) and $52.5 \%$ of the secondary school students (115 persons) reported experiencing three or more previous sunburns (Fig. 2). Secondary school students reported more frequently at least five episodes of sunburn than their younger counterparts, which was a significant difference $(P=0.007)$

\section{Indoor tanning (sunbeds)}

Sunbeds were used by $6.9 \%$ of students (Table 1 ). Although more secondary school pupils used sunbeds (15.1\%), 2.3\% of elementary school students also reported using them. Most of the students reported a desire for trendy brown skin as their reason for using sunbeds.

\section{Sun protection behaviour according to the age group and gender}

$32.2 \%$ of students reported wearing sun-protective clothing, and $65.7 \%$ of students used sunscreen during sunny days. Girls of all ages preferred sunscreen, while boys tended to use sun-protective clothing for sun protection. Among primary school students, significantly more 
Table 1. Sunbathing and sun protection habits of primary and secondary school students

\begin{tabular}{|c|c|c|c|}
\hline Statements & $\begin{array}{l}\text { Primary school } \\
n=393 \\
(64.2 \%)\end{array}$ & $\begin{array}{l}\text { Secondary school } \\
n=219 \\
(35.8 \%)\end{array}$ & $P$-value \\
\hline Purposely sunbathed & $17(4.3 \%)$ & $15(6.9 \%)$ & $0.18 \dagger$ \\
\hline Use of sunscreens & $276(70.2 \%)$ & $126(57.5 \%)$ & $0.0015^{* \prime}$ \\
\hline Wear sun-protective clothing & $125(31.8 \%)$ & $72(32.9 \%)$ & $0.79 \ddagger$ \\
\hline Wear hat & $235(59.8 \%)$ & $90(41.1 \%)$ & $<0.0001 *$ \\
\hline Do not apply any sun protection method & $37(9.4 \%)$ & $25(11.4 \%)$ & $0.46 \dagger$ \\
\hline Use of sunbed & $9(2.3 \%)$ & $33(15.1 \%)$ & $<0.0001^{*} \uparrow$ \\
\hline
\end{tabular}

* Significant at $P<0.05$.

$\uparrow$ Fisher's exact test.

tChi-squared test.

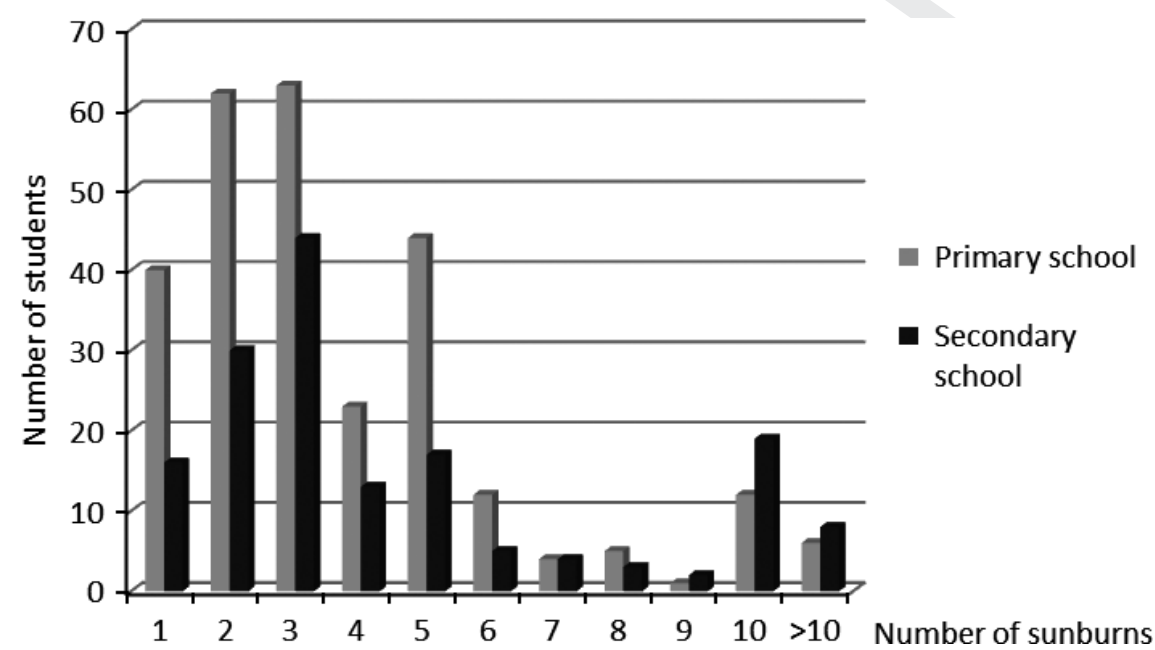

Fig. 2. Number of self-reported sunburns for primary and secondary school students in summer.

students applied sunscreens and wore hats. The results are summarised in Table 2.

\section{Use of sunscreens}

Most of the students of all skin types preferred the use of sun protection factor (SPF) 15 to 30 sunscreens (56.0\% of younger girls, $39.0 \%$ of older girls, $46.0 \%$ of younger boys, and $39.0 \%$ of older boys). Sunscreens with an $\mathrm{SPF}>30$ were used by $15.0 \%$ of primary school boys, $6.0 \%$ of secondary school boys, $11.0 \%$ of primary school girls, and $10.0 \%$ of secondary school girls.

\section{Use of hats}

Primary school students of all skin types liked wearing a hat (type I: $57.0 \%$, type II: $61.0 \%$, type III: $62.0 \%$ ), whereas fewer secondary school students used hats as a sun protection method (type I: $44.0 \%$, type II: $41.0 \%$, type III: $42.0 \%$ ).

\section{PHYSICAL EXAMINATIONS BY THE SCHOOL DOCTORS}

The naevi were typically located on the trunk. Most of the students had 5-20 naevi $(55.1 \%$ of primary school students and $54.8 \%$ of secondary school students). In total, $22.6 \%$ of students in the younger age group and $11.9 \%$ of students in the older age group had fewer than five naevi. Moreover, $20.7 \%$ of the primary school students and $27.2 \%$ of the secondary school students had multiple (more than 20) naevi, and only $1.6 \%$ of the younger students and $6.0 \%$ of the older pupils had no naevi.

According to the school doctors' evaluations, 59.0\% and $37.0 \%$ of the students had one or two atypical naevi, respectively, and $3.0 \%$ of the primary and $1.0 \%$ of the secondary school pupils had more than 10 atypical naevi. Overall, the school doctors discovered atypical naevi on $67.0 \%$ of the students. 
Table 2. Distribution of sun protection behaviour by age and gender among primary and secondary school students

\begin{tabular}{|c|c|c|c|c|c|}
\hline & $\begin{array}{l}\text { Do not go } \\
\text { outside when } \\
\text { the sun is } \\
\text { shining }\end{array}$ & $\begin{array}{l}\text { Appropriate } \\
\text { clothing for } \\
\text { sun protection }\end{array}$ & $\begin{array}{l}\text { Use of } \\
\text { sunscreens }\end{array}$ & $\begin{array}{l}\text { Do not wear } \\
\text { any sun-protective } \\
\text { clothing and hat }\end{array}$ & $\begin{array}{l}\text { Do not use any } \\
\text { sun protection } \\
\text { method }\end{array}$ \\
\hline \multicolumn{6}{|c|}{ Primary school, $n=377$} \\
\hline $\begin{array}{l}\text { Boy } \\
\qquad 42.0 \%(n=155)\end{array}$ & $7.0 \%(11)$ & $49.0 \%(76)$ & $33.0 \%(51)$ & $4.5 \%(7)$ & $6.5 \%(10)$ \\
\hline $\begin{array}{l}\text { Girl } \\
\quad 58.0 \%(n=222)\end{array}$ & $4.0 \%(8)$ & $22.0 \%(49)$ & $58.0 \%(129)$ & $4.0 \%(9)$ & $12.0 \%(27)$ \\
\hline \multicolumn{6}{|c|}{ Secondary school, $n=214$} \\
\hline $\begin{array}{l}\text { Boy } \\
\quad 49.0 \%(n=104)\end{array}$ & $5.0 \%(5)$ & $43.0 \%(45)$ & $32.0 \%(33)$ & $10.0 \%(10)$ & $11.0 \%(11)$ \\
\hline $\begin{array}{l}\text { Girl } \\
\quad 51.0 \%(n=110)\end{array}$ & $4.0 \%(4)$ & $24.0 \%(27)$ & $51.0 \%(56)$ & $8.0 \%(9)$ & $13.0 \%(14)$ \\
\hline
\end{tabular}

\section{PHYSICAL EXAMINATION OF THE STUDENTS WHO COMPLETED ELIGIBLE QUESTIONNAIRES}

Of the students who properly completed the questionnaire (612 students), the school doctors' evaluations indicated that $21.4 \%$ of them had skin type I, $60.8 \%$ had skin type II, $16.5 \%$ had skin type III, and $1.3 \%$ had skin type IV. The majority of the students $(55.5 \%$ of primary school and $51.6 \%$ of secondary school students) had 5-20 naevi that were usually located on the trunk. Multiple (more than 20) naevi were discovered on $23.7 \%$ of the students in the younger age group and $27.9 \%$ of the students in the older age group. Furthermore, $18.3 \%$ of the primary school students and $15.1 \%$ of the secondary school students had fewer than five naevi; and $2.6 \%$ of the younger students and $5.5 \%$ of the older students had no naevi.

\section{INFLUENCING FACTORS OF SUNBURN AND NUMBER OF NAEVI}

We analysed the factors that influence sunburns (gender; skin, hair, and eye colour; sunbathing habits; use of sunscreen and clothing as sun protection methods) using binomial logistic regression analyses. Sunbathing at age $12-15$ years $(P=0.04)$, lack of wearing sun-protective clothing during sunbathing at age $12-15$ years $(P=0.037)$, and male gender at age $15-19$ years increased the chance of experiencing sunburn $(P=0.035)$ (Table 3).

Furthermore, we investigated whether a correlation exists between the number of naevi and each factor (skin colour, sunbathing, tanning bed use, history of sunburn) using multinomial logistic regressions. A significant association with skin type was observed.
Table 3. Investigation of factors influencing sunburn with binomial logistic regression

\begin{tabular}{lll}
\hline Increased chance for sunburn & & \\
\hline Variables & $P$-value & OR \\
\hline Primary school & & \\
Sunbathing* & 0.040 & 1.79 \\
Do not wear any clothes and hat $\dagger$ & 0.037 & 2.37 \\
Secondary school & 0.035 & 2.35 \\
Boył & & \\
\hline
\end{tabular}

Factors: gender, skin-, hair-, eye colour, sunbathing, application of sunscreens and sun-protected clothing.

$\mathrm{OR}$, odds ratio.

*Reference: do not sunbathing.

$\dagger$ Reference: clothing for sun protection.

tReference: girl.

Students with skin types I and II were more likely to develop more than 20 naevi $(P=0.001)$. Furthermore, students who visited tanning salons were twice as likely to develop more than 20 naevi $(P=0.04)$ (Table 4$)$.

\section{DISCUSSION}

Considering that childhood sunburns are an important risk factor for skin cancer development and that effective educational programmes must be started early at school, we thought it was valuable to determine the sun protection behaviours, sunbathing habits, skin types, and numbers of naevi in this young population in our geographical region.

Regarding sun protection behaviours, most of the students in our study group used sunscreen $(84.0 \%$ and 
Table 4. Investigation of factors influencing number of naevi with multinomial logistic regression

\begin{tabular}{lll}
\hline Increased chance for naevi (>20 pcs) & \\
\hline Variables & P-value & OR \\
\hline Skin type I* & 0.001 & 4.83 \\
Skin type II* & 0.001 & 3.76 \\
Use indoor tanning devices† & 0.040 & 2.19 \\
\hline
\end{tabular}

Factors: skin type, sunbathing, tanning bed, sunburn.

OR, Odds ratio.

*Reference: skin type III.

$\dagger$ Reference: do not use indoor tanning devices.

$83.0 \%$ of primary school girls and boys and $79.0 \%$ and $73.0 \%$ of secondary school girls and boys, respectively), the SPF rating of which was mostly $15-30$ (50.0\% of the pupils). Sun-protective clothing was used by $32.2 \%$ of the students. Most of the students liked wearing a hat, especially younger students. Despite the fact that a high percentage of the pupils reported using some type of sun protection methods, $74.0 \%$ of them reported having had at least one severe sunburn. Although a low percentage of the students sunbathed during midday hours, $63.6 \%$ of them spent at least $4 \mathrm{~h} /$ day outside during the summer.

The application of sun protection methods and sunburn prevalence varies among countries and age groups (22-25). For example, $72.1 \%$ of primary school students who live in a coastal area of Greece reported that they always apply sunscreen, in addition, $40.6 \%$ of these students wear a hat, and $46.3 \%$ prefer to stay in the shade on the beach (22). Accordingly, $66.9 \%$ of the students said they had no sunburn last summer (22). Among 11to 14-year-old Italian children, also few pupils reported having experienced a sunburn $(24.0 \%)$, although $38.0 \%$ of these students reported to spend $4-8 \mathrm{~h}$ outside daily during the summer, and $30.0 \%$ were outside during midday, but $80.0 \%$ of them reported applying sunscreen (23). By contrast, in a study that was conducted in the southern part of Brazil, where the prevalence of fairskinned individuals is high, it was found that although $74.3 \%$ of the students ( $84.7 \%$ of the females) used sunscreen, the prevalence of experience with at least one sunburn was $73.0 \%$ (24). It was confirmed in another Brazilian survey that $70.8 \%$ of the preschool children were outside at a more critical period, between 10 a.m. and 4 p.m., and although fair-skinned children were more likely to apply sunscreen, they did not do that regularly (25). Other surveys (22-31) have got to the same conclusion, namely, in spite of the relatively high percentages of students who reported using sunscreen and who were willing to wear a hat and stay in the shade, the percentage of sunburns is high, just as in our study group.

We investigated the factors that influence experiencing sunburns, including gender; skin, hair, and eye colour; sunbathing habits; and the use of sunscreen and clothing as sun protection methods. We observed that secondary school boys exhibited an increased likelihood of experiencing sunburn. Moreover, we identified a positive correlation between sunbathing and sunburns and also between the lack of using appropriate clothing as a sun protection method and sunburns (Table 3).

We involved school doctors with the intention of assessing the potential for training them to improve the primary care prevention system.

School doctors discovered a high number of naevi and atypical naevi on the students. Most of the pupils had more than five but fewer than 20 naevi. The number of detected naevi was higher in the older age group. Most of the naevi were located on the trunk in both groups. In addition, $67.0 \%$ of the students had at least one clinically atypical naevi based on the school doctors' evaluations. In our study, the doctors most likely overestimated the number of atypical naevi despite their dermatological training. It was also shown (32) that doctors without sufficient experience are more likely to overestimate the number of atypical naevi in their first evaluations. In addition, the routine use of dermoscopy improves the skills of primary care physicians in assessing the clinical atypia of a naevi and can reduce the number of unnecessary excisions (33). More frequent and intense dermatological training should be provided for school doctors to help them reliably evaluate naevi, but their increased attention might aid in skin cancer prevention.

In another study that was conducted in southern Hungary, most of the secondary school students studied had 10-100 naevi (34). In a Spanish survey, a mean of 19 naevi per pupil was observed, particularly on fairskinned 10-year-old boys on both the trunk and sunexposed sites (35) and also in a study conducted in the USA, Colorado, the number of naevi was more than 20 among very light-skinned children (36).

The presence of multiple naevi reflects genetic susceptibility and/or photodamage and is a predisposing factor to $M M(14,15)$. In our study, students who had skin types I or II and who used sunbed were more likely to have more than 20 naevi. Notably, the proportion of tanning bed users was relatively high (15.1\%) among 
older students; and even $2.3 \%$ of primary school students tried indoor tanning. Contrary to (35), but similar to Buendia-Eisman et al. (34), we could not identify any correlation between the number of naevi and sunbathing habits or sunburns. In some studies, the avoidance of sunbathing, education regarding appropriate clothing, and the use of sunscreen and hats have been reported to delay the development of new naevi and, therefore, lower the risk of $\mathrm{MM}$, especially among individuals with skin type I (7, 16, 37-39). However, another study did not find any evidence regarding the protective effect of sunscreen against the development of new melanocytic naevi in fair-skinned children (40).

The incidence of MM in Hungary is high compared with the European average $(4,6)$. At present, the best approach for reducing the mortality of MM seems to be the improvement of primary and secondary prevention and screening strategies $(41,42)$. In Hungary, there are not yet any sun protection and awareness programmes such as those that have been implemented in the USA (43-45) and Australia (46). Observations in these studies support the need for consistent counselling with children and their parents regarding the appropriate use of sun protection, which is also confirmed by other studies (47, 48). Moreover, environmental interventions, such as the use of shade structures, are also required to support educational lessons (49), besides combined behavioural and political interventions (50).

We conclude that in order to increase sun-safe behaviour as well as decreasing the incidence of skin tumors, it is essential to educate students and their parents about appropriate sun protection and sun behaviour in Hungary. Such educational programmes would be most efficient when coupled with the intense cooperation of dermatologists and school doctors, who should be much more involved and educated in the primary prevention of MM. It is necessary to begin health education for children as early as possible (42). If addressed in this manner, some factors that increase the risk of developing MM could be avoided (sunburns during childhood, sun-related skin damage, development of new moles) $(42,51)$.

The effectiveness of such health education programmes can be determined by long-term follow-up studies.

\section{ACKNOWLEDGEMENTS}

This work was supported by the European Social Fund TÁMOP-4.2.2.A-11/1/KONV-2012-0031 and the Hungarian Scientific Research Fund OTKA K68401. We would like to say thanks for the participation of the principals, school doctors and last but not least students who have taken part in the study.

\section{SUPPORTING INFORMATION}

Additional Supporting Information may be found in the online version of this article:

Table S1. Application of different sun protection factor (SPF) sunscreens according to the age, gender and skin type $(n=570)$.

\section{REFERENCES}

1. Ferlay J, Steliarova-Foucher E, LortetTieulent $\mathrm{J}$ et al. Cancer incidence and mortality patterns in Europe: estimates for 40 countries in 2012. Eur J Cancer 2013; 49: 1374-1403.

2. Godar DE. Worldwide increasing incidences of cutaneous malignant melanoma. J Skin Cancer 2011; 2011: 858425.

3. Forsea AM, Del Marmol V, de Vries E, Bailey EE, Geller AC. Melanoma incidence and mortality in Europe: new estimates, persistent disparities. $\mathrm{Br} J$ Dermatol 2012; 167: 1124-1130.

4. MacKie RM, Hauschild A, Eggermont AM. Epidemiology of invasive cutaneous melanoma. Ann Oncol 2009;20(Suppl 6): vil-vi7.

5. Fartasch M, Diepgen TL, Schmitt J, Drexler $\mathrm{H}$. The relationship between occupational sun exposure and nonmelanoma skin cancer: clinical basics, epidemiology, occupational disease evaluation, and prevention. Dtsch Arztebl Int 2012; 109: 715-720.

6. Liszkay G. Klímaváltozás és bördaganatok. Magyar Tudomány 2011; 172: 147-153.

7. Bauer J, Buttner P, Wiecker TS, Luther H, Garbe C. Risk factors of incident melanocytic nevi: a longitudinal study in a cohort of 1,232 young German children. Int J Cancer 2005; 115: 121-126.

8. Carli P, Biggeri A, Giannotti B. Malignant melanoma in Italy: risks associated with common and clinically atypical melanocytic nevi. J Am Acad Dermatol 1995; 32: 734-739.

9. Dodd AT, Morelli J, Mokrohisky ST, Asdigian N, Byers TE, Crane LA.
Melanocytic nevi and sun exposure in a cohort of colorado children: anatomic distribution and site-specific sunburn. Cancer Epidemiol Biomarkers Prev 2007; 16: 2136-2143.

10. Whiteman DC, Brown RM, Purdie DM, Hughes MC. Melanocytic nevi in very young children: the role of phenotype, sun exposure, and sun protection. J Am Acad Dermatol 2005; 52: $40-47$.

11. Feher K, Cercato MC, Prantner I et al. Skin cancer risk factors among primary school children: investigations in Western Hungary. Prev Med 2010; 51: 320-324.

12. Cho E, Rosner BA, Feskanich D, Colditz GA. Risk factors and individual probabilities of melanoma for whites. J Clin Oncol 2005; 23: 2669-2675. 
13. Maier T, Korting HC. Sunscreens which and what for? Skin Pharmacol Physiol 2005; 18: 253-262.

14. Meyer LJ, Zone JH. Genetics of cutaneous melanoma. J Invest Dermatol 1994; 103: 112S-116S.

15. Elwood JM, Jopson J. Melanoma and sun exposure: an overview of published studies. Int J Cancer 1997; 73: 198-203.

16. Autier P, Severi G, Pedeux $R$ et al. Number and size of nevi are influenced by different sun exposure components: implications for the etiology of cutaneous melanoma (Belgium, Germany, France, Italy). Cancer Causes Control 2003; 14: 453-459.

17. Pettijohn KJ, Asdigian NL, Aalborg J et al. Vacations to waterside locations result in nevus development in Colorado children. Cancer Epidemiol Biomarkers Prev 2009; 18: 454-463.

18. Gallagher RP, Spinelli JJ, Lee TK. Tanning beds, sunlamps, and risk of cutaneous malignant melanoma. Cancer Epidemiol Biomarkers Prev 2005; 14: 562-566.

19. Bolognia J, Jorizzo J, Schaffer JV. Bolognia Dermatology, 3rd edn. New Heaven, CT, USA: Elsevier, 2012.

20. Holly EA, Kelly JW, Shpall SN, Chiu $\mathrm{SH}$. Number of melanocytic nevi as a major risk factor for malignant melanoma. J Am Acad Dermatol 1987; 17: 459-468.

21. Williams C, Quirk C, Quirk A. Melanoma: a new strategy to reduce morbidity and mortality. Australas Med J 2014; 7: 266-271.

22. Saridi M, Toska A, Rekleiti $M$ et al. Sun-protection habits of primary students in a coastal area of Greece. J Skin Cancer 2012; 2012: 629652.

23. Stinco G, Favot F, Quinkenstein E, Zanchi M, Valent F, Patrone P. Children and sun exposure in the northeast of Italy. Pediatr Dermatol 2005; 22: 520 524.

24. Batista T, Fissmer MC, Porton KR, Schuelter-Trevisol F. Assessment of sun protection and skin cancer prevention among preschool children. Rev Paul Pediatr 2013; 31: 17-23.

25. Dupont L, Pereira DN. Sun exposure and sun protection habits in high school students from a city south of the country. An Bras Dermatol 2012; 87: 90-95.

26. Wright CY, Brogniez C, Ncongwane KP et al. Sunburn risk among children and outdoor workers in South Africa and Reunion Island coastal sites. Photochem Photobiol 2013; 89: 1226-1233.

27. Suppa M, Cazzaniga S, Fargnoli MC, Naldi L, Peris K. Knowledge, perceptions and behaviours about skin cancer and sun protection among secondary school students from Central Italy. J Eur Acad Dermatol Venereol 2013; 27: 571-579.

28. Buendia-Eisman A, Conejo-Mir J, Prieto L, Castillejo I, Moreno-Gimenez JC, Arias-Santiago S. "Buen Rayito Study": awareness, attitudes and behavior of teenagers to sunlight through a web based system in Spain. Eur J Dermatol 2013; 23: 505-509.

29. Reinau D, Meier C, Gerber N, Hofbauer GF, Surber C. Sun protective behaviour of primary and secondary school students in North-Western Switzerland. Swiss Med Wkly 2012; 142: w13520.

30. Benvenuto-Andrade C, Zen B, Fonseca G, De Villa D, Cestari T. Sun exposure and sun protection habits among highschool adolescents in Porto Alegre, Brazil. Photochem Photobiol 2005; 81: 630-635.

31. Yurtseven E, Ulus T, Vehid S, Koksal S, Bosat M, Akkoyun K. Assessment of knowledge, behaviour and sun protection practices among health services vocational school students. Int J Environ Res Public Health 2012; 9: 2378-2385.

32. Katalinic A, Waldmann A, Weinstock MA et al. Does skin cancer screening save lives?: an observational study comparing trends in melanoma mortality in regions with and without screening. Cancer 2012; 118: 5395-5402.

33. Menzies SW, Emery J, Staples $M$ et al. Impact of dermoscopy and short-term sequential digital dermoscopy imaging for the management of pigmented lesions in primary care: a sequential intervention trial. $\mathrm{Br} J$ Dermatol 2009; 161: 1270-1277.

34. Csoma Z, Erdei Z, Bartusek D et al. The prevalence of melanocytic naevi among schoolchildren in South Hungary. J Eur Acad Dermatol Venereol 2008; 22: 1412 1422.

35. Buendia-Eisman A, Palau-Lazaro MC, Arias-Santiago S, Cabrera-Leon A, Serrano-Ortega S. Prevalence of melanocytic nevi in 8- to 10 -year-old children in Southern Spain and analysis of associated factors. $J$ Eur Acad Dermatol Venereol 2012; 26: 1558-1564.

36. Aalborg J, Morelli JG, Mokrohisky ST et al. Tanning and increased nevus development in very-light-skinned children without red hair. Arch Dermatol 2009; 145: 989-996.

37. Gallagher RP, McLean DI, Yang CP et al. Suntan, sunburn, and pigmentation factors and the frequency of acquired melanocytic nevi in children. Similarities to melanoma: the Vancouver Mole Study. Arch Dermatol 1990; 126: 770-776.

38. Quatrano NA, Dinulos JG. Current principles of sunscreen use in children. Curr Opin Pediatr 2013; 25: 122-129.
39. Green AC, Wallingford SC, McBride P. Childhood exposure to ultraviolet radiation and harmful skin effects: epidemiological evidence. Prog Biophys Mol Biol 2011; 107: 349-355.

40. de Maleissye MF, Beauchet A, Saiag P et al. Sunscreen use and melanocytic nevi in children: a systematic review. Pediatr Dermatol 2013; 30: 51-59.

41. Manganoni AM, Cainelli T, Zumiani G et al. Study of sunbathing in children: the preliminary evaluation of a prevention program. Tumori 2005; 91: 116-120.

42. Moyer VA. Behavioral counseling to prevent skin cancer: U.S. Preventive Services Task Force recommendation statement. Ann Intern Med 2012; 157: 59-65.

43. Hunter S, Love-Jackson K, Abdulla R et al. Sun protection at elementary schools: a cluster randomized trial. J Natl Cancer Inst 2010; 102: 484-492.

44. Roetzheim RG, Love-Jackson KM, Hunter SG et al. A cluster randomized trial of sun protection at elementary schools. Results from year 2. Am J Prev Med 2011;41:615-618.

45. Cohen L, Brown J, Haukness H, Walsh L, Robinson JK. Sun protection counseling by pediatricians has little effect on parent and child sun protection behavior. J Pediatr 2013; 162: 381-386.

46. Volkov A, Dobbinson S, Wakefield M, Slevin T. Seven-year trends in sun protection and sunburn among Australian adolescents and adults. Aust N Z J Public Health 2013; 37: 63-69.

47. Dobbinson SJ, White V, Wakefield MA et al. Adolescents' use of purpose built shade in secondary schools: cluster randomised controlled trial. BMJ 2009; 338: b95.

48. Cercato MC, Nagore E, Ramazzotti V, Sperduti I, Guillen C. Improving sunsafe knowledge, attitude and behaviour in parents of primary school children: a pilot study. J Cancer Educ 2013; 28: 151-157.

49. Wollina U, Helm C, Bennewitz A, Koch $\mathrm{R}$, Schaff $\mathrm{K}$, Burroni M. Interventional three-year longitudinal study of melanocytic naevus development in preschool children in Dresden, Saxony. Acta Derm Venereol 2014; 94: 63-66.

50. Olson AL, Gaffney C, Starr P, Gibson JJ, Cole BF, Dietrich AJ. SunSafe in the Middle School Years: a community-wide intervention to change early-adolescent sun protection. Pediatrics 2007; 119: e247-e256.

51. Rigel DS, Friedman RJ, Kopf AW. The incidence of malignant melanoma in the United States: issues as we approach the 21st century. J Am Acad Dermatol 1996; 34: 839-847. 


\section{Author Query Form}

Journal: $\quad$ PHPP

Article: $\quad 12219$

Dear Author,

During the copy-editing of your paper, the following queries arose. Please respond to these by marking up your proofs with the necessary changes/additions. Please write your answers on the query sheet if there is insufficient space on the page proofs. Please write clearly and follow the conventions shown on the attached corrections sheet. If returning the proof by fax do not write too close to the paper's edge. Please remember that illegible mark-ups may delay publication. Many thanks for your assistance.

\begin{tabular}{|c|c|c|}
\hline Query reference & Query & Remarks \\
\hline 1 & $\begin{array}{l}\text { AUTHOR: A running head short title was not supplied; please check if } \\
\text { this one is suitable and, if not, please supply a short title of up to } 40 \\
\text { characters (including spaces) that can be used instead. }\end{array}$ & \\
\hline 2 & $\begin{array}{l}\text { AUTHOR: Please confirm that given names (red) and surnames/family } \\
\text { names (green) have been identified correctly. }\end{array}$ & \\
\hline 3 & $\begin{array}{l}\text { AUTHOR: Please check that the legend for Figure } 1 \text { has been correctly } \\
\text { followed. }\end{array}$ & \\
\hline 4 & $\begin{array}{l}\text { AUTHOR: Please check that the legends for Tables } 1 \text { to } 4 \text { have been } \\
\text { correctly followed. }\end{array}$ & \\
\hline 5 & $\begin{array}{l}\text { AUTHOR: Supplied Tables ( } 1 \text { to } 4) \text { are in picture format. Therefore, we } \\
\text { re-keyed tables from } 1 \text { to } 4 \text {. Please check tables carefully. }\end{array}$ & \\
\hline 6 & $\begin{array}{l}\text { AUTHOR: Please provide an appropriate table footnote to explain the } \\
\text { bold values in Table } 2 .\end{array}$ & \\
\hline 7 & $\begin{array}{l}\text { AUTHOR: Figure } 1 \text { has been saved at a low resolution of } 172 \text { dpi. Please } \\
\text { resupply at } 600 \mathrm{dpi} \text {. Check required artwork specifications at http:// } \\
\text { authorservices.wiley.com/bauthor/illustration.asp }\end{array}$ & \\
\hline 8 & $\begin{array}{l}\text { AUTHOR: Figure } 2 \text { has been saved at a low resolution of } 155 \text { dpi. Please } \\
\text { resupply at } 600 \mathrm{dpi} \text {. Check required artwork specifications at http:// } \\
\text { authorservices.wiley.com/bauthor/illustration.asp }\end{array}$ & \\
\hline
\end{tabular}




\section{Please correct and return this set}

Please use the proof correction marks shown below for all alterations and corrections. If you wish to return your proof by fax you should ensure that all amendments are written clearly in dark ink and are made well within the page margins.

\begin{tabular}{|c|c|c|}
\hline Instruction to printer & Textual mark & Marginal mark \\
\hline Leave unchanged & ... under matter to remain & ( \\
\hline $\begin{array}{l}\text { Insert in text the matter } \\
\text { indicated in the margin }\end{array}$ & $h$ & $\begin{array}{l}\text { New matter followed by } \\
h \text { or } h \otimes\end{array}$ \\
\hline Delete & $\begin{array}{l}\text { I through single character, rule or underline } \\
\text { or }\end{array}$ & $\sigma$ or $\sigma / \otimes$ \\
\hline $\begin{array}{l}\text { Substitute character or } \\
\text { substitute part of one or } \\
\text { more word(s) }\end{array}$ & / through letter or & $\begin{array}{l}\text { new character / or } \\
\text { new characters / }\end{array}$ \\
\hline Change to italics & — under matter to be changed & $\leftarrow$ \\
\hline Change to capitals & $\equiv$ under matter to be changed & $\equiv$ \\
\hline Change to small capitals & $=$ under matter to be changed & $=$ \\
\hline Change to bold type & $\sim$ under matter to be changed & $\sim$ \\
\hline Change to bold italic & $\approx$ under matter to be changed & $\underline{s i n}$ \\
\hline Change to lower case & Encircle matter to be changed & $\not$ \\
\hline Change italic to upright type & (As above) & \\
\hline Change bold to non-bold type & (As above) & \\
\hline Insert 'superior' character & $\begin{array}{l}\text { I through character or } \\
K \text { where required }\end{array}$ & $\begin{array}{l}y^{\prime} \text { or } y \\
\text { under character } \\
\text { e.g. } y^{2} \text { or } y^{2}\end{array}$ \\
\hline Insert 'inferior' character & (As above) & $\begin{array}{l}\text { L } \\
\text { over character } \\
\text { e.g. } \hat{\imath}\end{array}$ \\
\hline Insert full stop & (As above) & $\odot$ \\
\hline Insert comma & (As above) & , \\
\hline Insert single quotation marks & (As above) & $\begin{array}{l}\dot{y} \text { or } \dot{X} \text { and/or } \\
\dot{y} \text { or } \dot{X}\end{array}$ \\
\hline Insert double quotation marks & (As above) & $\begin{array}{l}\ddot{y} \text { or } \ddot{y} \text { and/or } \\
\ddot{y} \text { or } \ddot{x}\end{array}$ \\
\hline Insert hyphen & (As above) & $1-1$ \\
\hline Start new paragraph & $\digamma$ & 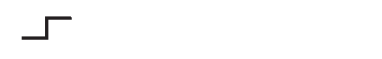 \\
\hline No new paragraph & $\infty$ & $\omega$ \\
\hline Transpose & $\sqcup$ & ᄃ \\
\hline Close up & linking $\bigcirc$ characters & \\
\hline $\begin{array}{l}\text { Insert or substitute space } \\
\text { between characters or words }\end{array}$ & $\begin{array}{l}\text { I through character or } \\
\Lambda \text { where required }\end{array}$ & \\
\hline $\begin{array}{l}\text { Reduce space between } \\
\text { characters or words }\end{array}$ & $\begin{array}{l}\text { between characters or } \\
\text { words affected }\end{array}$ & $\uparrow$ \\
\hline
\end{tabular}

